\title{
Interest groups, local politics, and police unions
}

\author{
Daniel DiSalvo $^{1}$ (1)
}

Accepted: 2 December 2021 / Published online: 23 January 2022

(c) The Author(s), under exclusive licence to Springer Nature Limited 2021

\begin{abstract}
Police unions raise issues of great importance for political scientists. Yet, the field has neglected them. This essay argues that political scientists should see police unions as important interest groups, empowered by state collective bargaining laws, that are important players in local politics and shapers of the criminal justice system in America. The organizational properties that make police unions important interest groups are described. The important political questions that arise once we consider police union as interest groups are examined. The existing research on police unions - especially their impact on government costs and police behavioris detailed. Ultimately, the study of collective bargaining in law enforcement and police union political activity in local politics has been overlooked because it lies at the intersection of three different streams of scholarly research-interest groups, local politics, and policing.
\end{abstract}

Keywords Police unions · Local politics · Interest groups · Public sector unions · Urban politics

\section{Introduction}

The protests and riots that followed George Floyd's death at the hands of the Minneapolis police in the summer of 2020 signaled a major breakdown between police and urban Americans. Liberals and conservatives quickly converged on the view that police unions were partly to blame for Floyd's death. The unions were said to have negotiated contracts, lobbied for laws, and instilled an organizational culture that kept bad cops on the beat. Tragedy ensued.

Political science, however, has contributed little to our knowledge of the role of police unions in American policing or local politics. Yet police and their unions raise issues of great importance for the field. Law enforcement is a central domestic

Daniel DiSalvo

ddisalvo@ccny.cuny.edu

1 Department of Political Science, City College of New York-CUNY, 160 Convent Avenue, NAC

4/136, New York, NY 10031, USA 
policy in the USA over which local governments have primary authority. Unions represent officers' occupational interests in collective bargaining and by lobbying government. Collective bargaining agreements (CBAs) set pay scales, benefit levels, and work rules that shape how departments operate. As a result, police unions are deeply engaged in local politics. They endorse candidates, donate to their campaigns, and negotiate contracts with local officials. Through collective bargaining they also have a hand in apportioning power between labor and management and thereby shape police departments' organizational culture.

Here, I argue that political scientists have much work to do to understand the consequences of police union activity at the bargaining table and in local politics and how they shape of America's criminal justice system. First, I discuss why police unions have been neglected and where they fit, or should fit, within the political science literature. Second, I describe the organizational properties that behoove scholars to conceptualize them as interest groups, empowered by state collective bargaining laws, and examine the important political questions that arise once we consider as such. Third, I examine the existing research on police unions-especially their impact on local government costs and police behavior. Finally, I sketch the possible contours of future scholarship on police unions. Only with more research on police unions can political science better position itself to explain the events of 2020-and the political behavior of law enforcement in America more generally.

Beyond the obvious challenge of securing appropriate data, I conclude that police unions have been neglected because they have not fit neatly into any of the major lines of inquiry in the discipline. Instead, they have fallen through the cracks between interest groups, local politics, and police behavior. This is unfortunate because policing is the subject of much recent political contestation and, as recent scholarship has shown, is fundamental to assessments of the quality of American democracy, citizens' conception of the state, and political scientists' theoretical understandings of these matters. The stakes are high.

\section{Interest groups, local politics, and policing}

The study of interest groups at all levels of government once held pride of place in the American politics subfield. But normative concerns and methodological problems pushed it to the margins. Rather than begin with interest group conflict, the dominant theoretical approach in the field has followed Downs' (1957) "median voter theorem." According to that logic, office-seeking politicians in a two-party system appeal to the center of the ideological distribution, and policy outcomes roughly conform to the preferences of the median voter. Consequently, voters, campaigns, elections, and legislator ideology have been the central objects of study. Inquiry into sub-national politics, the details of public policy, or interest group struggles for influence over outcomes have been shunted aside (Hacker and Pierson 2014; Anzia 2019).

Dissatisfaction with the dominant Downsian approach has led to recent calls to make interest groups more central to American politics research (Bawn et al., 2012, Hacker and Pierson 2011, 2014, Moe 2011, Anzia 2019). Heeding the call, the study 
of public sector unions, in particular, has emerged as a major research agenda (Moe 2009, 2011, 2015, Hartney and Flavin 2011; Anzia and Moe 2015, 2016, 2019; Flavin and Hartney 2015; DiSalvo 2015; DiSalvo and Kucik 2018; Walker 2014, 2020; Hertel-Fernandez 2018; Finger and Hartney 2019; Paglayan 2019; Zupan 2017). Yet, scholars have so far paid much more attention to teachers unions than unions representing police, firefighters, or corrections officers. There are many reasons for this focus, including the fact that K-12 schools are the largest slice of state and local government employment, the availability of data, the prominent role teachers unions play in the Democratic Party, and the importance of public education to the nation's civic health. But the consequence is that other public sector unions, especially those representing police, have been overlooked.

Meanwhile, the study of local governments has been on the back-burner for decades. While once central to the discipline-and the area of study where some of the field's most famous scholars first made their mark-political scientists of recent generations have focused on national institutions, national policies, and federal campaigns and elections (Anzia 2019, 2020). Only in the last ten years or so have political scientists have begun to take an interest again in local governments (Oliver 2012; Anzia 2011, 2013; Tausanovitch and Warshaw 2013, 2014a, b; Anzia and Moe 2015; Einstein and Kogan 2016; Schaffner et al. 2020). However, much of the current work on local politics seeks to show that it is ideological and partisan like national politics (Anzia 2020). The guiding question has been whether the policy positions of local political elites align with the preferences of urban residents-with the finding being that they generally do (Tausanovitch and Warshaw 2014a, b; Einstein and Kogan 2016; Warshaw 2019).

The risk of approaching local politics using methods imported from national politics is that many of the particularities of local politics and local policies get lost in translation (Anzia 2020). Because power is diffuse and obscurely allocated in the American federal system, local government policies are distinct from other levels (Derthick 2001). So too is their politics because local policies shape local politics (Schattschneider 1935). Political debate in American cities often hinges on issues such as repairing pot holes, maintaining parks, collecting trash, removing snow, running public transit systems, and providing police and fire protection. These issues do not find direct analogues in national politics and policy. As New York City Mayor Fiorello La Guardia famously quipped, "There is no Democratic or Republican way of cleaning the streets."

The politics of policing is highly complex in the American federal system. Recent federalism scholarship has argued that at lower levels of government, especially the local level, policies are more easily captured by concentrated interests (Miller 2008a, 2008b, Michener 2018; Grumbach 2020). Miller (2008a, 2008b) has argued that federalism gives organized interests a disproportionate influence in local crime politics, skewing policies in favor of the police. Furthermore, local policing defies the partisan and ideological structure of national politics. For local elected officials, law enforcement generates cross-pressures that confound partisan and ideological categories. For instance, some urban Democrats may be skeptical of the police due to their perceived negative impact on minority communities, but those same Democrats tend to be favorable to unions, collective bargaining, and better compensation 
for public employees. On the other hand, Republicans tend to be favorable to law enforcement but skeptical of the value of unions and collective bargaining.

Furthermore, unlike other public employees who provide public goods, police often develop an adversarial relationship with the people and communities they serve. Police work, while not as dangerous as commercial logging or fishing, can place officers in danger and expose them to stressful and difficult situations. Black Americans in particular have extremely low levels of trust in the police (Howell et al. 2004). Black Americans also report more confrontational and violent encounters with police (Epp et al. 2014, Lerman and Weaver 2014a, Baumgartner, Epp, and Shoub 2009, Fryer 2019, Edwards, Lee, and Esposito 2019; Pierson et. al 2020). Racial politics and policing are closely linked in many cities. In sum, we should expect local law enforcement to generate politics that are quite different from other levels of government.

Police behavior itself has not been an area of great interest in political science and has remained distant from the major preoccupations of the field (for an exception, see Wilson 1968). But this too is beginning to change as recent work by prominent scholars has pushed the discipline to take more interest in local policing, especially its impact on minorities communities (Lerman and Weaver 2014a, 2014b; Hinton 2016; Fortner 2015; Soss and Weaver 2017, Baumgartner, Epp, and Shoub 2009). A number of calls have been issued that the field should seek to correct this imbalance of attention and encourage the study of policing and related criminal justice operations (Isaac 2015). The aim of this research is to elucidate how local policing shapes America's racial politics from the bottom up, starting with local communities. An important argument in this literature is that for minority communities in urban centers, policing is the face of the state, which leads to a very different assessment of the quality of American democracy than when policing is ignored (Soss and Weaver 2017).

Putting it all together, the study of collective bargaining in law enforcement and police union political activity in local politics lies at the intersection of three different streams of scholarly research-interest groups, local politics, and policing. As a result, while there is a small scholarly literature on police unions, they have been almost completely ignored by political scientists (Walker 2008). The one recent study of the role of police unions by a political scientist focuses on their role in the 2016 US presidential election (Zoorab 2018). However, focusing on police unions role in a presidential election, while of great value, misses the lion's share of their activity and influence, which is at the state and local levels.

That police unions can link such disparate research agendas should be a powerful motivator to put them at the forefront of future inquiry. They raise profound questions for the American politics subfield. Because local governments are the primary decisions makers for law enforcement, answers to these questions are essential to understanding local government in America. But the field is illequipped to answer basic questions. What is police unions role in local politics? What are the effects of police unions and collective bargaining on the cost of police protection? How do they affect the organization of core agencies of local governance and shape police behavior? Do they impact public perceptions of the police? What are the connections between police union political activity, local 
elections, and public policy? Despite the obvious importance of these questions, it is noteworthy that to date not a single study of police unions in US local politics has been published in any of the top political science journals (for a possible exception, see Anzia and Moe 2015). ${ }^{1}$

\section{Police unions as interest groups}

Over the last decade, public employee unions have attracted a great deal of scholarly interest. Such unions took off in the 1960s and 1970s only to have their power curtailed in the 2010s (DiSalvo 2015; Anzia and Moe 2016; Walker 2014, 2020; Hertel-Fernandez 2018; Finger and Hartney 2019). As part of this larger movement, police unions became important players in American urban politics. They should be seen as key interest groups, as their leaders inevitably have influence on reforms touching on public safety and exercise power inside and outside of city government.

The organizational basics that make police unions into potent interest groups derive from state laws and local ordinances. Today, police have collective-bargaining rights in 41 states and the District of Columbia, and union locals are dispersed across the roughly 18,000 police departments nationwide. Only Georgia, North Carolina, South Carolina, and Tennessee prohibit bargaining for public employees, ${ }^{2}$ while Alabama, Colorado, Mississippi, and Wyoming lack statutes to either advance or oppose police unions. Police are some of the most heavily unionized segments of the state and local workforce in the USA. The Bureau of Labor Statistics' Current Population Survey found that in $2019,57.5 \%$ of the nation's 712,336 police officers were covered by collective-bargaining contracts, and $55 \%$ of officers were union members. In addition, there were 80,802 police supervisors and detectives, $40.6 \%$ of whom were union members and $43.3 \%$ of whom were covered by union contracts.

Police unions' relationship with American labor movement is complex. Only 15\% to $20 \%$ of law-enforcement employee organizations affiliate with the AFL-CIO. The largest police organization, the Fraternal Order of Police (FOP), has roughly 354,000 members, but it does not affiliate with any of the major labor federations. The second largest is the National Association of Police Organizations, with some 236,000 members, and maintains ties to the International Brotherhood of Police Officers, which is chartered by the American Federation of Labor and Congress of Industrial Organizations (AFL-CIO). Other major union federations also count police locals among their affiliates, including American Federation of State, County and Municipal Employees (AFSCME); the Service Employees International Union (SEIU); the

\footnotetext{
1 Anzia and Moe (2015) studied the costs to government of allowing police and firefighters to bargain collectively. The paper was framed as being about collective bargaining and costs rather than focusing on police unions per se. I discuss this paper at greater length below.

2 Until 2021, Virginia prohibited collective bargaining for all public employees. Beginning in May 2021, Virginia began to permit local governments to collective bargain with their employees-including public school teachers, firefighters, police officers, and most other local government employees. Virginia House Bill 582 was adopted in April 2020, but its implementation was postponed or a year due to the COVID19 pandemic.
} 
Communications Workers of America (CWA); and the International Brotherhood of Teamsters (DeLord et al 2008).

Evidence suggests that police unions have the resources to be important organizations shaping electoral politics (Leighey and Nagler 2007). They are active political groups but they tend to be more bi-partisan than other public sector unions or the labor movement as a whole. This can be seen in their political spending, which tends to support both political parties. While the teachers' unions typically give over $90 \%$ of their campaign contributions to Democratic candidates for federal offices, police unions and associations gave $61 \%$ of their contributions to Democrats and $39 \%$ to Republicans in 2018 (Open Secrets 2020). In state politics, police unions tend to even more evenly split their contribution between Democrats and Republicans (DiSalvo and Kucik 2018). One reason Wisconsin Governor Walker exempted police unions from his signature collective bargaining reform legislation (Act 10) was because police unions were large contributors to the Wisconsin Republican Party. Nonetheless, Democrats enjoy an edge in police union campaign contributions because they are perceived as more favorable to organized labor than are Republicans. Democrats are also the dominant party in most of America's largest cities with the largest police forces.

Candidate endorsements are another way police unions wield political influence (Sieg and Wang 2013; Zoorob 2018). Not only does an endorsement carry signaling value to voters, it can also serve as a stamp of approbation for other potential endorsers or donors. As with campaign contributions, police endorsements tend to be more bipartisan. But there has been little study of the impact of endorsements on the local level.

Police unions are also active participants in the local public square. Union leaders are often in the media and the unions may hold rallies and other events that attract local press attention (Feuer 2020). This is because the extension of collective bargaining rights to police encouraged the creation of organizations that are politically savvy and experienced in public relations. Among police unions core tasks is to defend their members from citizen complaints about officer behavior and disciplinary action from superiors. Not only are union leaders legally obligated to defend all members equally - in legal terms, a duty of fair representation-but internal leadership election incentives encourage such behavior. Failure to vigorously defend every officer can expose a union president to challenges in the next leadership election. Therefore, when an officer is accused of abuse or misconduct, the union typically launches a legal defense within the police department following the procedural mechanisms detailed in state statute or the CBA. In high profile cases, the union will mount a major public relations offensive in defense of the accused officer.

Many media stories, government studies, and activist reports suggest that police unions have negotiated contracts that strongly shape the operations of police departments (US Department of Justice 2000, US Conference of Mayors 2020, Campaign Zero 2016). They have pointed to ways in which grievance and arbitration provisions in contracts can tie the hands of police chiefs (Delaney and Feuille 1985). In that respect, they can be seen as "interest groups on the inside" (Anzia and Moe 2019). Yet, political scientists have not studied how unionization affects the organization and management of police departments (Marobito 2014). Understanding 
the variation in these local bureaucratic cultures - from the New York City Police Department with its 36,000 officers (the largest paramilitary force in the nation) to departments in medium sized cities to departments in small localities-is hugely important. Layered on top of state and local policies is the controversial legal doctrine of qualified immunity that protects police officers accused of violating constitutional rights and developed out of the federal courts. No studies yet exist on whether qualified immunity has encouraged more aggressive police behavior.

To arrive at where we are today, it is clear that police unions are a significant part of the labor movement with a rich history but their origins and development have not been intensely studied by students of American Political Development. Consider that the first associational activity of police occurred in 1892 when officers formed New York City's Patrolmen's Benevolent Association to raise money for widows of officers slain in the line of duty. Over the ensuing three decades, there was a debate within the American labor movement over whether police associations should be allowed to join it. Samuel Gompers of the American Federation of Labor (AFL) delayed chartering police unions due to concern over the potential "divided loyalty" of police when they tasked with handling union-led strikes.

The potential political power of police associations came to national attention with the Boston police strike of 1919. Denied the right to unionize by the police commissioner about 80 percent of the police force struck and three days of rioting ensued. Massachusetts Governor Calvin Coolidge sent in 7,000 state militiamen to restore order. To do so, state guards killed nine people and wounded 23. The city then fired and replaced all 1,147 officers who struck.

Labor historian Joseph Slater (2017) documents the damage the strike caused for the police unionization movement in particular and the unionization of public employees in general. For the next forty years, bipartisan opposition to the unionization of public employees was widespread. State and local government workers were disregarded for inclusion in the National Labor Relations Act of 1935 (Walker 2020). Consequently, it was not until a wave of state legislation in the 1960s and 1970s granted state and local government employees collective-bargaining rights that most police officers gained them as well. But much of the detail of this political and policy history remains to be told.

\section{Government costs and police behavior}

The little work, mostly by economists, that treats police unions as local interest groups focuses on their impact on government costs (Feuille and Delaney 1986; Zax 1988; Ichniowski et al. 1989; Trejo 1991; Valletta 1993; Chandler and Gely 1995; Briggs et al 2008; Doerner and Doerner 2010; Frandsen 2016). Although this work was on the right track, the bulk of it is over 25 years old, and never quite gained the momentum needed to answer key questions with confidence. Today's scholars should now revisit these issues and build on the earlier studies but also raise new questions and bring new data and methods to bear on them.

Recently, Anzia and Moe (2015) used two data sets to study cities from 1972 to 1987 , when many cities began collectively bargaining for the first time, and 
from 1992 to 2010, to see whether unionized cities had higher wages, health benefits, and employment levels for police officers than non-union cities. They found strong evidence that allowing police to collectively bargain increased the costs of municipal government. They did so because active police unions that recently gained collective bargain rights increased wages by $2.3 \%$, staffing also increased by the same percentage per capita, such that combining wages and employment resulted in an average $3.7 \%$ increase in per capita payroll expenditures for police. They also found that cities where police had enjoyed collective bargaining for some time spent $4.3 \%$ more on salaries per capita and about $16.5 \%$ more on health benefits per capita. This indicates that police unions tend to have more sway over benefits than wages, which is highly salient for municipal budgets.

Beyond costs, scholars have explored other effects of police collective bargaining and unionization. Regarding the power of unions to shape elections, Zoorob (2018) studied the impact of the Fraternal Order of Police's (FOP) endorsement of Donald Trump in 2016. The FOP had refused to endorse Mitt Romney for president in 2012 due to his opposition to public sector unionism but it endorsed Donald Trump in 2016. This was a rare instance of variation in interest group behavior between two election cycles. Analyzing it, Zoorob found that FOP lodge density contributed to a significant swing in vote share from Romney to Trump. The endorsement was especially valuable to Trump in key swing states. But this study was on the power of police union endorsements in national elections. That they are powerful at that level is striking because we should suppose such endorsements to carry the least weight in the crowded field of US national politics. We should expect police union endorsements to carry even greater value in local politics.

Although endorsements have received some attention, there is no work to date on the impact (if any) of police union campaign contributions at the local level. Breathless news reports often tabulate large sums donated by the unions to local and state candidates. But little systematic work has been done to show if these campaign contributions have any effects.

In another area of the electoral universe, one study has explored whether police unions-along with other unions including teachers, firefighters, and construction workers-encouraged members to seek public office at the state level (Sojourner 2013). The finding was that compared with the percentage of legislators of the same occupation in states with lower unionization rates, the percentage of legislators from a given occupation in a state increases with that occupation's unionization rate in that state. The conclusion was that public sector unions, including police unions, promoted public office seeking by citizens from middle- and working-class jobs. However, no other papers have examined the influence (if any) of police unions or other public sector unions on local office holding.

When it comes to the impact of police unions on public policy, especially in the area of criminal justice, a handful of scholars have used case studies to argue that unions impede criminal justice police reform (Epp 2009, Fisk and Richardson 2017, Bies 2017). Similar to what Moe (2011) has argued in the case of teachers unions, this work suggests that police unions engage in a "politics of blocking" to prevent changes to the organization and operation of police departments that they perceive 
would negatively impact their members occupational interests. Police unions may not always get what they want but they are effective at stalling reform.

Meanwhile, legal scholars and economists have been particularly interested in the extent to which CBAs affect police behavior, especially whether CBAs protect bad officers from discipline for misconduct and thereby increase the amount of violence visited on citizens by the police (Rushin 2017; Rad 2018; Edwards et al 2019). In the most innovative study to date, Dharmpala, McAdams, and Rappaport (2020) investigate whether union protections led to more police misconduct. They find quasi-experimental evidence that law enforcement collective bargaining rights increases police violence against civilians. To make their case, they use a 2003 Florida Supreme Court decision that conferred collective bargaining rights on sheriffs' deputies. Using a state administrative database of violations from 1996 to 2015, they tested differences between police departments, who already had collective bargaining rights, and sheriffs' offices that just acquired them. They found that extending collective bargaining rights to sheriffs led to a substantial increase in violent incidents of misconduct in comparison with police departments. In a separate analysis, they also found that unionization to be associated with greater violent misconduct.

Another working paper by economists (Cunningham et al. 2021) found that after officers gained collective bargaining rights there was a substantial increase in killings of civilians. Specifically, the authors found that collective bargaining rights explained roughly 10 percent of the total fatal encounters between non-white civilians and law enforcement between 1959 and 1988. A key finding is collective bargaining rights causes deaths by non-whites to increase even if overall deaths at the hands of law enforcement do not go up.

Other work, however, has not found that police unions are connected with increased police violence, or at least police killings of civilians specifically. In a working paper, Goncalves (2021) examined the staggered rollout of unionization across departments nationwide and unionization patterns in Florida and found that the impact of unionization was small and statistically insignificant. He concludes that although unions reduce civilian oversight and increase legal protection for officers, they do not increase misconduct.

Still other research has tried to establish the effect of police union communications on the internal culture of police departments and officers' attitudes (Marobito 2014). However, the number of such studies remains limited. Political scientists have yet to bring to bear on police departments any of the analytic tools that they have developed in the study of bureaucracies and administrative agencies.

\section{Looking ahead}

The above discussion suggests that many avenues of inquiry remain to be pursued. Police unions' political activities at the local level have not been systematically studied. We know little about their endorsement strategies and whether those endorsements shape local election outcomes. We know little about the effects (if any) of police unions campaign spending on local elections because no studies of them exist. We know little about police effects on public perceptions of the police because no 
one has yet studied unions activities in the public square. These questions couldn't be more basic but they have not been addressed.

To assess the political activity of police unions, scholars might use ICMA survey data to show that police unions both make endorsements and use collective bargaining to influence policy outcomes. ${ }^{3}$ As for police collective bargaining rights, scholars can look to data compiled by Freeman and Valletta (1988), updated by Reuben (1996), and then updated again by Dippel and Sauers (2019). For union membership data, there is the Bureau of Labor Statistics Community Population Survey as well as what individual unions themselves report.

Another big part of a future research agenda on police unions should be to suss out and assess the extent to which they impact the quality of American democracy at the local and state levels. Such work might examine the extent to which the preferences of mass publics or police unions are better reflected in criminal justice policies. For instance, Caughey and Warshaw (2018) develop new yearly summary measures of public opinion and government policy liberalism in the states that are comparable over the 1936-2014 period. Such data might be leveraged to test the impact of police unionization on various policies related to policing and their responsiveness to citizen preferences.

Scholars might also explore police unions' potential impact on public trust or confidence in the performance of the police. On the one hand, collective bargaining could reduce trust in the police, as work rules in contracts protect bad officers and thereby poison community relations. On the other hand, collective bargaining - to the extent it gives rise to labor organizations that are effective advocates for officers and can tell "the cops' side of the story"-might actually increase public trust in police. Survey data that asks questions about trust in the police or police performance might be useful. Researchers might inquire into whether cities with CBA provisions that protect officers are associated with lower citizen evaluations of the police using the Harvard University's Cooperative Election Study data. ${ }^{4}$ Enterprising scholars might design survey experiments to test whether unionization impacts perceptions of the police. Many citizens are probably unaware if their local police are unionized and that officers are defended by the union. Researchers could "treat" respondents with some vignettes about policy brutality and how the union's responded and see how (if at all) they changed responses.

The study of police unions also presents challenges for a number of recent studies of organized labor. Some have found that labor unions can reduce political inequality and increase policy responsiveness on behalf of lower-income citizens (Alquist 2017, Flavin 2018, Becher and Stegmueller 2020). But if police unions push for a more punitive criminal justice system, can this be squared with the preferences of urban minority communities? As organized interests, do police unions mute the preferences of subjugated groups? Other recent work finds that union membership lowers racial resentment (Frymer and Grumbach 2021). But is that true for police unions? If so, how does that comport with findings that police more frequently

\footnotetext{
3 https://icma.org/survey-research-datasets

${ }^{4}$ https://cces.gov.harvard.edu/
} 
target minorities? Some scholars have asserted that "police unions have contributed to racism" (Ajunwa et al 2020) but systematic study to prove such claims has yet to be done. Pairing data on collective bargaining laws or union membership rates with white attitudinal data might be a way to get at this question.

Another important question for the quality of American democracy is whether police unionization increases police violence against civilians, which has been the subject of a few recent studies (e.g., Rad 2018, Dharmapala et al. 2020, Goncalves 2021, Cunningham et al. 2021). However, the connection has yet to be fully established. Political scientists can and should contribute to this debate. Scholars might use Rad's (2018) data set, which codes the restrictiveness of police CBA's, to see if they correlate with worse police behavior.

Many other questions about the impact of collective bargaining on the structure of police departments and the behavior of officers are also relevant to political science. Indeed, the policies of greatest interest to police unions, like other public employee unions, are personnel policies on wages, health benefits, pensions, and work rules. Decisions in these areas have large impacts on local budgets. To the extent that police unions extract higher rents, they create significant opportunity costs as there is less revenue available for other priorities.

Looking ahead, treating police unions as important interest groups in local politics promises to broaden and deepen our knowledge of American politics and government. Insofar as the organization and operations of the police influence their effectiveness in fighting crime as well as public perceptions of the police, there is much more for political scientists to do. Indeed, the study of police unions has the opportunity to touch the fundamentals of American democracy-its representativeness and responsiveness to citizens, especially those from minority communities. Beyond the concerns of scholars themselves, answers to questions about police unions, police behavior, and local governments are central to what students, policymakers, and the public want to know.

\section{Declarations}

Conflict of interest All authors have declare that they have no conflict of interest.

\section{References}

Ajunwa, Ifeoma, Virginia Doellgast, Shannon Gleeson, Kate Griffith, and Verónica Martínez-Matsuda. 2020. A call for radical labor solidarity with the \#BlackLivesMatter movement. Cornell: ILR Worker Institute, Cornell University.

Anzia, S.F. 2011. Election timing and the electoral influence of interest groups. Journal of Politics 73(2): 412-27.

Anzia, S.F. 2013. Timing and turnout: How off-cycle elections favor organized groups. Chicago: University of Chicago Press.

Anzia, S.F. 2019. Looking for influence in all the wrong places: How studying subnational policy can revive research on interest groups. Journal of Politics 81(1): 343-51. 
Anzia, Sarah F. 2020. Party and ideology in american local government: An appraisal. Annual Review of Political Science. 24: 1.

Anzia, Sarah F., and Terry M. Moe. 2015. Public sector unions and the costs of government. Journal of Politics 77(1): 114-127.

Anzia, Sarah F., and Terry M. Moe. 2016. Do politicians use policy to make politics? The case of publicsector labor laws. American Political Science Review 110(4): 763-777.

Anzia, S.F., and M.M. Terry. 2019. Interest groups on the inside: The governance of public pension funds. Perspectives on Politics 17(4): 1059-78.

Ahlquist, John. 2017. Labor unions, political representation, and economic inequality. Annual Review of Political Science 20: 409-432.

Bawn, Kathleen, Martin Cohen, David Karol, Seth Masket, Hans Noel, and John Zaller. 2012. A theory of political parties. Perspectives on Politics 10(3): 571-597.

Becher, Michael, and Daniel Stegmueller. 2021. Reducing unequal representation: The impact of labor unions on legislative responsiveness in the U.S. congress. Perspectives on Politics 19(1): 92-109.

Bies, Kathleen. 2017. Let the sunshine In: Illuminating the powerful role police unions play in shielding officer misconduct. Stanford Law and Policy Review 28: 109-148.

Baumgartner, Frank R., Derek A. Epp, Kelsey Shoub. xxxx. Suspect citizens: What 20 million traffic stops tell us about policing and race. New York: Cambridge University Press.

Briggs, Steven J., Jihong Zhao, Steve Wilson, and Ling Ren. 2008. The effect of collective bargaining on large police agency supplemental compensation policies: 1990-2000. Police Practice and Research: An International Journal 9: 227-238.

Brown, Ben, Benedict, Wm Reed. 2002. Perceptions of the police: Past findings, methodological issues, conceptual issues and policy implications. Policing: An International Journal of Police Strategies \& Management 25: 543-80.

Campaign Zero. 2016 Police unions contracts and police bills of rights analysis. Report. June 29.

Caughey, Devin, and Christopher Warshaw. 2018. Policy preferences and policy change: Dynamic responsiveness in the American States, 1936-2014. American Political Science Review 112(2): 249-266.

Chandler, Timothy D., and Rafael Gely. 1995. Protective service unions, political activities, and bargaining outcomes. Journal of Public Administration Research and Theory 5(3): 295-318.

Cunningham, Jamein, Feir, Donna, and Rob Gillezeau. 2021. Collective bargaining rights, policing, and civilian deaths. IZA Discussion Paper No. 14208.

Delaney, John Thomas, and Peter Feuille. 1985. Collective bargaining, interest arbitration, and the delivery of police services. Review of Public Personnel Administration 5(2): 21-36.

DeLord, Ron, Jon Burpo, and Michael R. Shannon. 2008. Police union power, politics, and confrontation in the 21st century: New challenges, new issues. Springfield: Charles C. Thomas Publisher.

Dharmpala, Dhammika, Richard H. McAdams, and John Rappaport. 2020. Collective Bargaining Rights and Police Misconduct: Evidence from Florida. Journal of Law, Economics, \& Organization.

Derthick, Martha. 2001. Keeping the compound republic: Essays on American Federalism. Washington: Brookings Institution Press.

Dippel, Christian and Zachary Sauers. 2019. Does Increased Union Power Cause Pension Under-Funding in the Public Sector? Working paper.

DiSalvo, Daniel. 2015. Government against itself: Public union power and consequences. New York: Oxford University Press.

DiSalvo, Daniel, and Jeffrey Kucik. 2018. Unions, parties, and the politics of State Government legacy costs. Policy Studies Journal 46: 573-597.

Doerner, William M., and William G. Doerner. 2010. Collective bargaining and job benefits: The case of florida deputy sheriffs. Police Quarterly 13: 367-386.

Downs, Anthony. 1957. An economic theory of democracy. Addison Wesley.

Edwards, Frank, Hedwig Lee, and Michael Esposito. 2019. Risk of being killed by police use-of-force in the U.S. by age, race/ethnicity, and sex. In Proceedings of the National Academy of Sciences.

Einstein, K.L., and Valdimir Kogan. 2016. Pushing the city limits: Policy responsiveness in municipal government. Urban Affairs Review 52(1): 3-32.

Epp, Charles R. 2009. Making rights real: Activists, bureaucrats, and the creation of the legalistic state. Chicago, IL: University of Chicago Press.

Epp, Charles R., Steven Maynard-Moody, and Donald Haider-Markel. 2014. Pulled over: How police stops define race and citizenship. Chicago: University of Chicago Press. 
Feuer, Alan. 2020. How New York City's police unions embraced Trump. New York Times. September 14.

Feuille, Peter, and John Delaney. 1986. Collective bargaining, interest arbitration, and police salaries. Industrial and Labor Relations Review 39(2): 228.

Finger, Leslie and Michael Hartney. 2019. Financial solidarity: The future of labor unions in the postJanus era. Perspectives on Politics. 1-17.

Fisk, Catherine L., and Richardson, L. Song. 2017. Politce Unions. George Washington Law Review. Vol. 85, Is. 3, 712-799.

Flavin, Patrick. 2018. Labor union strength and the equality of political representation. British Journal of Political Science 48(4): 1075-1091.

Flavin, Patrick, and Michael T. Hartney. 2015. When government subsidizes its own: Collective bargaining laws as agents of political mobilization. American Journal of Political Science 59(4): 896-911.

Fortner, Micahel Javen. 2015. The silent black majority: The Rockfeller drug laws and the politics of punishment. Cambridge: Harvard University Press.

Frandsen, Brigham R. 2016. The effects of collective bargaining rights on public employee compensation: Evidence from teachers, firefighters, and police. Industrial and Labor Relations Review 69: 84-112.

Freeman, Richard and Robert Valletta. 1988. Appendix B: The NBER public sector collective bargaining law data set. When Public Sector Workers Unionize.

Fryer, Roland G., Jr. 2019. An empirical analysis of racial differences in police use of force. Journal of Political Economy 127: 1210-1261.

Frymer, Paul, and Jacob M. Grumbach. 2021. Labor unions and white racial politics. American Journal of Political Science 65(1): 225-240.

Goncalves, Felipe. 2021. Do police unions increase misconduct? UCLA Department of Economics working paper.

Greenfield, Lawrence A., Langan, Patrick A., and Smith, Steven K. 1997. Police use of force: Collection of national data. NCJ-165040. Washington, D.C.: U.S. Department of Justice, Office of Justice Programs, Bureau of Justice Statistics.

Grumbach, Jacob M. 2020. Interest group activists and the polarization of state legislatures'. Legislative Studies Quarterly 45(1): 5-34.

Hacker, Jacob S., and Paul Pierson. 2014. After the 'Master Theory': Downs, Schattschneider, and the rebirth of policy-focused analysis. Perspectives on Politics 12(3): 643-662.

Hacker, Jacob S., and Paul Pierson. 2010. Winner-take-all politics. New York: Simon \& Schuster.

Hartney, Michael, and Patrick Flavin. 2011. From the schoolhouse to the statehouse: Teacher union political activism and U.S. state education reform policy. State Politics \& Policy Quarterly 11(3): 251-268.

Harris, Christopher, and Matthew M. Sweeney. 2019. Police Union Contracts: An Analysis of Large Cities. Policing: A Journal of Policy and Practice.

Hertel-Fernandez, Alexander. 2018. Policy feedback as political weapon: Conservative advocacy and the demobilization of the public sector labor movement. Perspectives on Politics 16(2): 364-379.

Hinton, Elizabeth. 2016. From the war on poverty to the war on crime: The making of mass incarceration in America. Cambridge: Harvard University Press.

Howell, Susan E., and Deborah Fagan. 1988. Race and trust in government: Testing the political reality model. Public Opinion Quarterly 52(3): 343-350.

Howell, S.E., H.L. Perry, and M. Vile. 2004. Black Cities/White Cities: Evaluating the police. Political Behavior 26: 45-68.

Ichniowski, Casey, Richard B. Freeman, and Harrison Lauer. 1989. Collective Bargaining Laws, threat effects, and the determination of police compensation. Journal of Labor Economics 7(2): 191-209.

Isaac, Jeffery C. 2015. The American politics of policing and incarceration. Perspectives on Politics. 13: 609-616.

Keller, Michael H., and Kim Barker. 2021. Police Unions Won power using his playbook. Now He's Negotiating the Backlash. New York Times. March 10.

Leighley, Jan E., and Jonathan Nagler. 2007. Unions, voter turnout, and class bias in the US electorate, 1964-2004. Journal of Politics 69(2): 430-441.

Lerman, Amy E., and Vesla M. Weaver. 2014a. Arresting citizenship: The democratic consequences of American crime control. Chicago: University of Chicago Press. 
Lerman, Amy E., and Vesla M. Weaver. 2014b. Staying out of sight? Concentrated policing and local political action. The Annals of the American Academy of Political and Social Science. 651(1): 202-219.

Macdonald, J., and R.J. Stokes. 2006. Race, social capital, and trust in the police. Urban Affairs Review. 4(3): 358-375.

Michener, Jamila. 2018. Fragmented democracy: Medicaid, federalism, and unequal politics. New Yok: Cambridge University Press.

Miller, Lisa L. 2008a. The perils of federalism: Race, poverty, and the politics of crime control. New York: Oxford University Press.

Miller, Lisa L. 2008. The representational biases of federalism: Scope and bias in the political process, revisited. Perspectives on Politics 5(2): 305-321.

Morabito, Melissa. 2014. American police unions: A hindrance or help to innovation? International Journal of Public Administration 37: 1096.

Moe, Terry M. 2011. Special interest: Teachers unions and America's public schools. Washington, DC: Brookings Institution Press.

Moe, Terry M. 2015. Vested interests and political institutions. Political Science Quarterly 130(2): 277-318.

Moe, Terry M. 2009. Collective bargaining and the performance of the public schools. American Journal of Political Science 53(1): 156-174.

Oliver, J. Eric. 2012. Local elections and the politics of small-scale democracy. Princeton: Princeton University Press.

Open Secrets. 2020. Campaign Contributions by Police Unions to federal elections.

Paglayan, Augustina. 2019. Public-sector unions and the size of government. American Journal of Political Science 63(1): 21-36.

Pierson, E., C. Simoiu, J. Overgoor, et al. 2020. A large-scale analysis of racial disparities in police stops across the United States. Nature Human Behavior 4: 736-745.

Rad, Abdul. 2018. Police Institutions and police abuse: Evidence from the US. M.sc. thesis, University of Oxford.

Reuben, Kim. https://www.nber.org/research/data/nber-public-sector-collective-bargaining-law-data-set.

Rozema, Kyle, and Max Schanzenbach. 2019. Good cop, bad cop: Using civilian allegations to predict police misconduct. American Economic Journal 11(2): 225-268.

Rudolph, Thomas J., and Jillian Evans. 2005. Political trust, ideology, and public support for government spending. American Journal of Political Science 49(3): 660-671.

Rushin, Steven. 2017. Police union contracts. 66 Duke Law Journal 1191.

Rushin, Steven, and Atticus DeProspo. 2019. Interrogating police officers. George Washington Law Review 87(3): 646-705.

Schaffner, Brian F. Jesse H. Rhodes, and Raymond La Raja. 2020. Hometown inequality: Race, class, and representation in American local politics. Cambridge University Press.

Schattschneider, E.E. 1935. Politics, pressure, and the tariff. New York: Prentice-Hall.

Scholz, John T., and Mark Lubell. 1998. Trust and taxpaying: Testing the Heuristic approach to collective action. American Journal of Political Science 42(2): 398-417.

Sieg, Holger, and Yu. Wang. 2013. The impact of unions on municipal elections and urban fiscal policies. Journal of Monetary Economics 60(5): 554-567.

Slater, Joseph E. 2017. Public workers: Government employee unions, the Law, and the State, 19001962. Ithaca: ILR Press.

Sojourner, Aaron J. 2013. Do unions promote members' electoral office holding? Evidence from correlates of state legislatures' occupational shares. ILR Review. Vol. 66, Is. 2.

Soss, Joe, and Vesla Weaver. 2017. Police are our government: Politics, political science, and the policing of race-class subjugated communities. Annual Review of Political Science 20(1): 565-591.

Tausanovitch, Chris, and Christopher Warshaw. 2013. Measuring constituent policy preferences in congress, State Legislatures, and Cities. Journal of Politics 75(2): 330-342.

Tausanovitch, Chris, and Christopher Warshaw. 2014a. Representation in municipal government. American Political Science Review 108(3): 605-641.

Theobold, Nick A., and Donald P. Haider-Markel. 2009. Race, bureaucracy, and symbolic representation: Interactions between citizens and police. Journal of Public Administration Research and Theory 19: 409-426.

Trejo, Stephen J. 1991. Public sector unions and municipal employment. Industrial and Labor Relations Review 45: 166-180. 
U.S. Conference of Mayors. 2020. Report of Police Reform and Racial Justice. August.

U.S. Department of Justice. 2000. Sourcebook of Criminal Justice Statistics 1999. NCJ-183727. Washington, D.C.: Bureau of Justice Statistics.

Tausanovitch, Chris, and Christopher Warshaw. 2014b. Representation in municipal government. American Political Science Review 108(3): 605-641.

Tyler, Tom R. 2005. Policing in black and white: Ethnic group differences in trust and confidence in the police. Police Quarterly 8: 322-342.

Valletta, Robert. 1993. Union effect on municipal employment and wages: A longitudinal approach. Journal of Labor Economics 11: 545-574.

Valletta, R.G., and R.B. Freeman. 1988. The NBER Public Sector Collective Bargaining Law Data Set. Appendix B in Richard B. Freeman and Casey Ichniowski, editors, When Public Employees Unionize Chicago: NBER and University of Chicago Press.

Walker, Alexis N. 2014. Labor's enduring divide: The distinct path of public sector unions in the United States. Studies in American Political Development 28(2): 175-200.

Walker, Alexis N. 2020. Divided unions: The Wagner Act, federalism, and organized labor. Philadelphia: University of Pennsylvania Press.

Walker, Samuel. 2008. The neglect of police unions. Police Practice and Research. 9: 95-112.

Warshaw, Christopher. 2019. Local elections and representation in the United States. Annual Review of Political Science. 22: 461-479.

Wilson, James Q. 1968. The varieties of police behavior. Cambridge: Harvard University Press.

Zax, Jeffrey S. 1988. Wages, nonwage compensation, and municipal unions. Industrial 27: 301-317.

Zoorob, M. 2018. Blue endorsements matter: How the fraternal order of police contributed to Donald Trump's victory. PS: Political Science \& Politics 52(2): 243-250.

Zupan, Mark. 2017. Inside Job: How government insiders subvert the public interest. Cambridge: Cambridge University Press.

Publisher's Note Springer Nature remains neutral with regard to jurisdictional claims in published maps and institutional affiliations. 